\title{
The APplication Of ArChitecture Bahavioural StUdies for DeSign STRATEGY IN FEMALE STUDENT'S DORMITORY IN SLEMAN
}

\section{Penerapan Kajian Arsitektur Perilaku dalam Strategi Perancangan ASRAMa MaHaSisWi di SLEMAN}

\author{
Iqbal Maulana Fauzi ${ }^{1 *}$, Samsudi ${ }^{2}$, Agung Kumoro Wahyuwibowo ${ }^{3}$ \\ Program Studi Arsitektur, Fakultas Teknik, Universitas Sebelas Maret ${ }^{1}$ \\ iqbalmaulanafauzi@ student.uns.ac.id" \\ Program Studi Arsitektur, Fakultas Teknik, Universitas Sebelas Maret $^{2}$ \\ Program Studi Arsitektur, Fakultas Teknik, Universitas Sebelas Maret ${ }^{3}$
}

\begin{abstract}
Nowadays, education is such a global priority and because of it, it is necessary for citizen to continue their education from Senior High School to Higher Education stage. Special Region of Yogyakarta is one of the most favorite destination to continue higher education. According to some researches in 2015, 70\% of new university students came from outside Yogyakarta. Since there are so many students from outside Yogyakarta, the demand of student housing grows higher, especially for female students. A housing for students who came from outside Yogyakarta is necessary. This housing can be used as temporary place to live when they continue their study, while it also can support the student's selfdevelopment in academic or non-academic activity. There are so many options of housing for female students, but a dormitory is the best option. A dormitory is the best option of housing for female students that can be provided with self-development facilities in academic or non-academic activity. This dormitory will be designed in a good way, so the female students as the user could get comfortable, motivated, and optimal in developing themselves. This dormitory also has to provide a serenity and comfort while the students doing their activity. In order to get those criteria, a study about behavioral architecture should be applied as a design approach. The studies of behavioral architecture that will be applied in design strategy are spatial analysis, site analysis, mass composition analysis, structure system and material analysis, and utility system. The analysis process that apply architecture behavioral study can give a result of dormitory design which give comfort when the user living and doing self-development activity.
\end{abstract}

Keywords: student housing, dormitory, architecture behavioural studies

\section{PENDAHULUAN}

Setiap tahun jumlah lulusan Sekolah Menengah Umum (SMU) di Indonesia selalu meningkat dan peningkatan tersebut berbanding lurus dengan jumlah mahasiswa baru. Perguruan tinggi favorit menjadi incaran lulusan SMU untuk melanjutkan pendidikan tinggi walaupun perguruan tinggi favorit tersebut berada di luar daerah asal mereka.
Daerah Istimewa Yogyakarta menjadi salah satu daerah favorit bagi lulusan SMU untuk melanjutkan pendidikan tinggi karena terdapat banyak perguruan tinggi favorit dan ditunjang dengan iklim pendidikan yang baik dengan biaya hidup yang relatif murah. Rentang tahun 2011 - 2015, jumlah mahasiswa baru di D.I. Yogyakarta selalu mengalami peningkatan dengan sekitar 58.100 mahasiswa baru dari 83.000 mahasiswa baru merupakan mahasiswa dari luar D.I. Yogyakarta. 
Belum terdapat data spesifik mengenai kebutuhan hunian yang dibutuhkan oleh mahasiswa luar D.I. Yogyakarta namun bila membandingkan jumlah mahasiswa baru dengan mahasiswa yang lulus setiap tahunnya tidaklah seimbang yang secara tidak langsung menunjukan persediaan hunian untuk mahasiswa luar daerah tidak dapat memenuhi permintaan hunian mahasiswa baru.

Heilweil (1981) menyebutkan bahwa hunian mahasiswa selain menyediakan tempat tinggal sementara bagi mahasiswa hendaknya memberikan fasilitas pengembangan sesuai dengan tujuan utama dalam pendidikan tinggi yaitu pengembangan akademik maupun non akademik.

Hayes (1932) menyampaikan perlunya pertimbangan fungsional dan pertimbangan pengguna dalam perancangan bangunan hunian. Arsitektur dalam konteks ini tentu saja berperan dalam menciptakan rancangan bangunan yang mempertimbangkan aspek fungsional dan aspek pengguna.

Perencanaan dan perancangan asrama memerlukan sebuah metode desain agar persoalan - persoalan dapat terselesaikan secara arsitektural. Penerapan arsitektur perilaku dipilih sebagai pendekatan dalam proses perencanaan dan perancangan asrama mahasiswi.

\subsection{Arsitektur Perilaku}

Pendekatan arsitektur perilaku memperhatikan keterkaitan antara ruang dengan manusia yang memanfaatkan atau menghuni ruang tersebut terhadap kenyamanan dan gerak .

Arsitektur perilaku bukan merupakan teori tunggal namun didukung oleh kajian - kajian lain yang mendukung terhadap pemenuhan kenyamanan dan gerak manusia (Haryadi \& Setiawan, 2014). Kajian - kajian arsitektur perilaku adalah sebagai berikut.

\section{a. Setting Perilaku}

Setting perilaku adalah interaksi antar kegiatan yang dilakukan sekelompok orang dengan tempat dimana kegiatan tersebut dilakukan. Setting perilaku dilakukan dengan mengidentifikasi dan mengukur perilaku perilaku individu yang konstan atau berkala pada situasi atau setting tertentu. Hal yang diperhatikan dalam setting perilaku adalah perilaku dalam hal gerak, kebiasaan, keinginan, dan antropometri.

\section{b. Kualitas Lingkungan}

Kualitas lingkungan didefinisikan sebagai suatu lingkungan yang memenuhi preferensi imajinasi ideal seseorang atau sekelompok orang. Kualitas lingkungan seyogyanya dapat dipahami secara subjektif yaitu dikaitkan dengan aspek - aspek psikologis dan fisik.

Kualitas lingkungan ini dalam konteks psikologis mencakup privasi, warna, dan keamanan. Dalam konteks fisik mencakup tingkat kebisingan, tingkat penerangan, dan tingkat penghawaan. Hal yang diperhatikan dalam kualitas lingkungan yaitu ergonomi dan warna ruang.

\section{c. Ruang Personal}

Ruang personal mengatur seberapa dekat interaksi antar individu, berpindah, bergerak, meluas serta menyempit sesuai dengan situasi dan kegiatan dimana dan sedang individu lakukan (Halim, 2005).

Ruang personal berupa ruang imajiner yang mengelilingi individu berbentuk gelembung bulatan silinder. Ruang personal individu bersifat dinamis dan dimensi dapat berubah sesuai dengan situasi dan kegiatan yang sedang dilakukan oleh individu.

\section{d. Persepsi Lingkungan}

Persepsi lingkungan adalah proses manusia menerima informasi mengenai lingkungan sekitarnya dan bagaimana informasi fisik tersebut diorganisasikan kedalam pikiran manusia.

Persepsi lingkungan berkaitan dengan interpretasi manusia sebagai individu pengamat lingkungan terhadap suatu lingkungan.

Persepsi lingkungan manusia dapat berubah ubah yang disebabkan oleh pengalaman singkat atau pengalaman yang terjadi terus menerus.

Persepsi lingkungan tiap individu manusia dapat berbeda - beda. Faktor - faktor yang dapat membedakan persepsi lingkungan antara lain usia, gender, pendidikan, lingkungan budaya, profesi, dan pengalaman.

\subsection{Asrama Mahasiswi}

Asrama Mahasiswi adalah bangunan kategori perumahan sebagai tempat tinggal sementara bagi mahasiswi yang dimungkinkan memiliki sarana lingkungan untuk melengkapinya serta 
kegiatan - kegiatan pembinaan dan pengembangan baik secara akademik maupun non - akademik (Harris, 2006; Noguchi, 1978).

Persyaratan rancangan asrama mahasiswi yang ideal adalah sebagai berikut:

a. Unit hunian asrama mahasiswi harus mampu menampung minimal kegiatan belajar, tidur, sosialisasi, dan berpakaian.

b. Kualitas lingkungan unit hunian asrama mahasiswi harus memberikan pencahayaan yang cukup, ketenangan, dan suhu ruang yang nyaman.

c. Fasilitas - fasilitas penunjang di lingkungan asrama mahasiswi minimal harus tersedia fasilitas mandi cuci dan kakus, fasilitas makan, fasilitas rekreasi dan aktivitas sosial, fasilitas budaya, ruang servis dan gudang, serta sirkulasi.

\section{METODE}

Objek rancangan asrama mahasiswi dirancang dengan menerapkan kajian - kajian dalam teori arsitektur perilaku. Dalam tahap perencanaan dan perancangan bangunan asrama mahasiswi di Sleman diperluakan sebuah metode sebagai landasan pengerjaan - pengerjaan mulai awal sampai dengan selesainya rancangan asrama mahasiswi.

\subsection{Identifikasi Masalah dan Eksplorasi}

Tahap identifikasi masalah dan eksplorasi yang dilakukan dengan menggali isu - isu permasalahan hunian bagi mahasiswa luar D.I. Yogyakarta.

\subsection{Pengumpulan Pustaka dan Data}

Tahap pengumpulan pustaka dan data yang akan digunakan dalam menyelesaikan permasalahan dan persoalan.

\subsection{Perencanaan}

Tahap perencanaan yang terdiri dari dua sub tahap. Sub tahap pertama adalah pemograman fungsional yaitu berisi gambaran umum asrama mahasiswi yang direncanakan dan analisis pelaku dan pola kegiatan. Sub tahap kedua adalah pemograman performansi yaitu penerjemahan kebutuhan calon pemakai kedalam pernyataan karakteristik respon lingkungan binaan.

\subsection{Pemograman Arsitektur}

Tahap pemograman arsitektural yaitu penerjemahan pemograman fungsional dan performansi kedalam spesifikasi rancangan. Pemograman arsitektural terdiri dari:

a. Persoalan Peruangan

Persoalan peruangan akan terbagi menjadi empat sub bab yaitu (1) kegiatan dan kebutuhan ruang, (2) kualitas ruang, (3) pola hubungan ruang, dan (4) besaran ruang.

Persoalan kegiatan dan kebutuhan ruang akan menerapkan kajian arsitektur perilaku setting perilaku.

Persoalan kualitas ruang akan menerapkan kajian arsitektur perilaku kualitas lingkungan psikologis privasi dan kualitas lingkungan fisik tingkat pencahayaan, tingkat penghawaan, dan tingkat ketenangan.

Persoalan pola huhungan ruang akan dibahas secara umum.

Persoalan besaran ruang akan menerapkan kajian arsitektur perilaku setting lingkungan antropometrik dan ruang personal zona spasial.

b. Persoalan Tapak

Persoalan tapak dibagi ke dalam dua sub bab yaitu pemilihan tapak dan pengolahan tapak terhadap lingkungan fisik.

Kajian arsitektur perilaku yang diterapkan adalah (1) setting perilaku dan (2) kualitas lingkungan.

c. Persoalan Tampilan Bangunan

Persoalan tampilan bangunan terbagi menjadi lima sub bab yaitu persoalan (1) bentuk, (2) jenis koridor, (3) tampilan tanggap iklim, (4) warna ruang, dan (5) pengolahan lansekap.

Persoalan bentuk akan menerapkan kajian arsitektur perilaku persepsi lingkungan bentuk dan ruang.

Persoalan jenis koridor akan menerapkan kajian arsitektur perilaku kualitas lingkungan psikologis dan kualitas lingkungan fisik tingkat ketenangan, tingkat penghawaan, dan tingkat pencahayaan.

Persoalan tampilan tanggap iklim akan menerapkan kajian arsitektur perilaku kualitas lingkugan fisik tingkat penghawaan dan tingkat pencahayaan. 
Persoalan warna ruang akan menerapkan kajian arsitektur perilaku kualitas lingkungan psikologis warna ruang.

Persoalan pengolahan lansekap akan menerapkan kajian arsitektur perilaku persepsi lingkungan peta mental.

d. Persoalan Struktur

Persoalan struktur akan terbagi menjadi dua sub bab yaitu (1) material struktural dan (2) sistem struktur.

Baik persoalan material struktural dan sistem struktur akan menerapkan kajian arsitektur perilaku yaitu kualitas lingkungan psikologis keamanan.

\section{e. Persoalan Utilitas Bangunan}

Persoalan utilitas bangunan terbagi menjadi empat sub bab yaitu utilitas (1) mekanikal, (2) elektrikal, (3) pemipaan, dan (4) non mekanikal, elektrikal, dan pemipaan.

\subsection{Penyusunan Konsep}

Tahap penyusunan konsep merupakan penggabungan hasil terbaik yang sudah dikaji pada tahap pemograman arsitektural. Hasil dari tahap pemograman arsitektural akan diolah dan diterjemahkan ke dalam bentuk ungkapan fisik yang dikehendaki sesuai dengan daya kreatif perancang.

\subsection{Transformasi Desain}

Tahap transformasi desain akan melakukan studi lanjut mengenai konsep - konsep yang sudah didapatkan dan diolah menjadi sebuah desain skematik yaitu desain kasar yang memuat gambaran umum dari bangunan yang akan direncanakan dan dirancang.

\subsection{Studio Perancangan Arsitektur}

Tahap studio perancangan tugas akhir akan mendetailkan hasil dari transformasi desain kedalam gambar kerja dan maket.

\section{HASIL DAN PEMBAHASAN}

\subsection{Peruangan}

Kebutuhan ruang pada asrama mahasiswi didasarkan pada kegiatan pelaku - pelaku kegiatan yang mungkin terlibat dalam asrama mahasiswi, karakteristik kegiatan, dan kemungkinan pola kegiatan.
Pelaku - pelaku kegiatan yang mungkin terlibat pada asrama mahasiswi antara lain (1) mahasiswi sebagai penghuni asrama, (2) orang tua dan rekan mahasiswi sebagai pengunjung, dan (3) pengelola asrama.

Karakteristik kegiatan pada mahasiswi mencakup kegiatan hunian dan kegiatan yang menggunakan fasilitas bersama. Pada orang tua dan rekan mahasiswi mencakup kegiatan berkunjung. Pada pengelola asrama mencakup kegiatan bekerja administrasi dan bekerja pengelolaan dan pemeliharaan bangunan.

Pola kegiatan pada asrama mahasiswi lebih memperhatikan kegiatan hunian dan kegiatan pada hari aktif berkuliah. Selain itu juga memperhatikan karakteristik mahasiswi sendiri. Heilweil (1981) menjelaskan bahwa terdapat tiga karakter mahasiswi yaitu mahasiswi berkegiatan normal (academically), mahasiswi berkegiatan normal yang aktif berorganisasi dan ekstrakurikuler (collegiately), dan mahasiswi berkegiatan normal yang menyukai bersosialisasi (vocationally).

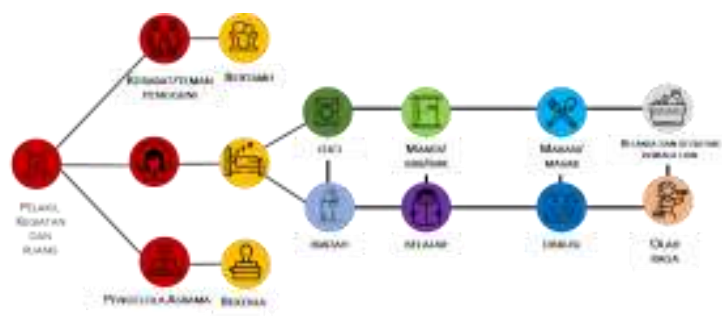

Gambar 1. Pelaku dan Kegiatan pada Asrama Mahasiswi

Kebutuhan ruang dapat dilihat pada Tabel 1.

Tabel 1. Kebutuhan Ruang Asrama Mahasiswi

\begin{tabular}{|c|c|}
\hline Kelompok Ruang & Ruang \\
\hline \multicolumn{2}{|c|}{ Kelompok Kegiatan Hunian } \\
\hline \multirow{3}{*}{$\begin{array}{ll}\text { Kelompok } & \text { Ruang } \\
\text { Hunian } & \end{array}$} & Area Istirahat \\
\hline & Area Belajar \\
\hline & Area Balkon \\
\hline \multirow{3}{*}{$\begin{array}{l}\text { Kelompok Ruang } \\
\text { Fasilitas Bersama }\end{array}$} & Kamar Mandi/WC \\
\hline & Ruang Bersama \\
\hline & Area Dapur \\
\hline \multicolumn{2}{|c|}{ Kelompok Kegiatan Fasilitas } \\
\hline \multirow{9}{*}{$\begin{array}{ll}\text { Kelompok } & \text { Ruang } \\
\text { Fasilitas } & \end{array}$} & Lobby \\
\hline & Pujasera \\
\hline & Komunal \\
\hline & Aula \\
\hline & Gym \\
\hline & Lapangan \\
\hline & Laundry \\
\hline & ATM \\
\hline & Mini - market \\
\hline
\end{tabular}




\begin{tabular}{|c|c|}
\hline Kelompok Ruang & Ruang \\
\hline & Toko Fotokopi dan Cetak \\
\hline & Klinik - Apotek \\
\hline & Toilet \\
\hline & Mushola \\
\hline \multicolumn{2}{|c|}{ Kelompok Kegiatan Pengelola } \\
\hline \multirow{8}{*}{$\begin{array}{ll}\text { Kelompok } & \text { Ruang } \\
\text { Pengelola } & \end{array}$} & R. Kepala Asrama \\
\hline & R. Sekretaris \\
\hline & R. Bagian Kedisiplinan \\
\hline & $\begin{array}{l}\text { R. Bagian Hubungan } \\
\text { Publik }\end{array}$ \\
\hline & $\begin{array}{l}\text { R. Bagian Pembinaan dan } \\
\text { Pengembangan }\end{array}$ \\
\hline & $\begin{array}{l}\text { R. Bagian Operasional, } \\
\text { Perawatan, dan } \\
\text { Manajamen Bangunan }\end{array}$ \\
\hline & Ruang Rapat \\
\hline & Ruang Tamu \\
\hline \multirow{2}{*}{$\begin{array}{ll}\text { Kelompok } & \text { Ruang } \\
\text { Istirahat } & \end{array}$} & Pantry \\
\hline & Mushola \\
\hline \multicolumn{2}{|c|}{ Kelompok Kegiatan Servis } \\
\hline \multirow[t]{15}{*}{ Kelompok Ruang Servis } & Parkir \\
\hline & R. Ganti Seragam dan APD \\
\hline & R. AHU \\
\hline & $\begin{array}{l}\text { R. Mesin Transportasi } \\
\text { Vertikal }\end{array}$ \\
\hline & R. Genset \\
\hline & R. Panel \\
\hline & R. CCTV \\
\hline & R. Pompa \\
\hline & R. GWT \\
\hline & R. STP \\
\hline & R. Keamanan \\
\hline & R. Janitor \\
\hline & R. Sampah \\
\hline & Loading Dock \\
\hline & Gudang \\
\hline
\end{tabular}

Setelah didapatkan kebutuhan ruang kemudian menentukan kualitas ruang. Kualitas ruang didasarkan pada perilaku mahasiswa yang membutuhkan kualitas lingkungan fisik dan psikologis.

Kualitas ruang dicapai dengan strategi penerapan kajian arsitektur perilaku lingkungan fisik dan psikologis. Secara umum kualitas lingkungan yang dikehendaki pada ruang dan strategi pencapaian kualitas lingkungan tersebut adalah (1) kualitas ruang memiliki privasi yang tinggi dicapai dengan (a) meletakan ruang jauh dari jangkauan pelaku yang tidak dikehendaki, dan (b) pembentuk ruang menggunakan bata ringan, (2) kualitas ruang memiliki pencahayaan yang baik dicapai dengan pemberian (a) pencahayaan alami dengan jendela dan curtain wall dan (b) pencahayaan buatan dengan lampu, (3) kualitas ruang memiliki penghawaan yang baik dan tidak gerah dicapai dengan pemberian (a) penghawaan alami dengan jedela, dan (b) penghawaan buatan dengan $\mathrm{AC}$, dan (4) ruang memiliki ketenangan yang tinggi dicapai dengan (a) meletakan ruang pada tempat yang jauh dari kebisingan dan (b) menggunakan material bata ringan sebagai pembentuk ruang.

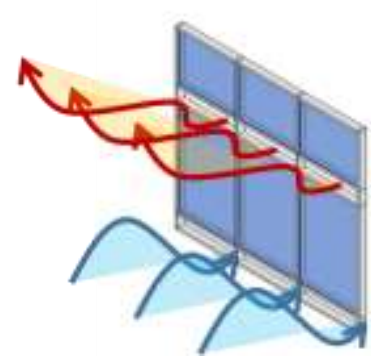

Gambar 2. Rancangan jendela dengan bukaan untuk sirkulasi silang

Kualitas ruang digunakan sebagai dasar penyusunan organisasi ruang berdasarkan kualitas ruang yang dikehendaki. Selain itu organisasi ruang mempertimbangkan hubungan kedekatan antar ruang. (Gambar 3).

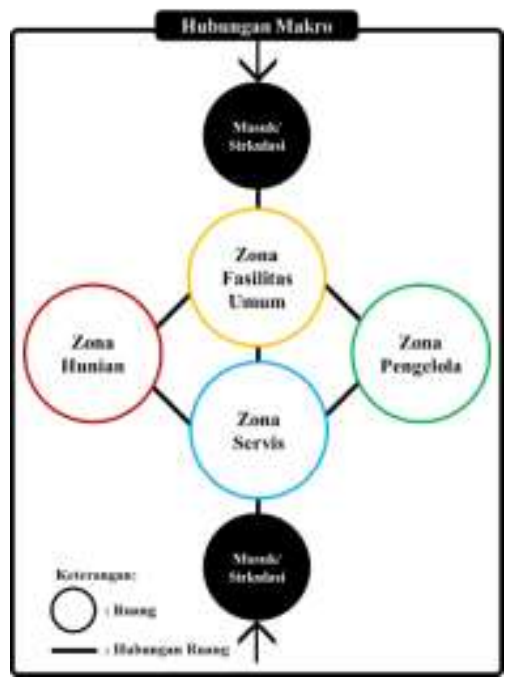

Gambar 3. Pola Hubungan Ruang Asrama Mahasiswi

Setelah itu ditentukan luas dan besaran ruang yang perhitungannya mempertimbangkan kebutuhan perabot dan sirkulasi pada ruang. Tahap - tahapan perhitungan luas dan besaran ruang pada asrama mahasiswi yaitu (1) mendaftar perabot yang mungkin digunakan dan jumlah perabot pada suatu ruang, (2) menghitung luas perabot berdasarkan antropometri, (3) menentukan zona personal yang mungkin terjadi pada suatu ruang berdasarkan kegiatan yang diwadahi ruang tersebut dan jumlah kapasitas ruang yang 
dikehendaki, (4) menghitung luas sirkulasi pada ruang berdasarkan zona spasial dan kapasitas jumlah orang dalam ruang, (5) menjumlah luas perabot dengan luas sirkulasi sehingga didapatkan luas ruang, dan (6) mengalikan luas ruang dengan tinggi dari lantai ke langit - langit untuk mendapatkan besaran ruang.

Perhitungan luas perabot diasumsikan bahwa perabot hanya memiliki dimensi panjang $(\mathrm{P})$ dan lebar (L). Sehingga untuk menghitung suatu perabot akan digunakan persamaan berikut:

$$
\mathrm{L}_{\text {Perabot }}=\mathrm{P} \times \mathrm{L}
$$

Perhitungan luas sirkulasi ditetapkan bahwa luas alas bangun silinder dikalikan kapasitas ruang (p). Sehingga untuk menghitung luas sirkulasi akan digunakan persamaan berikut:

$$
\mathrm{L}_{\text {Sirkulasi }}=\pi \times \mathrm{R}^{2} \times \mathrm{p} \quad \ldots \ldots \ldots
$$

Perhitungan luas ruang yaitu menambahkan luas perabot $\left(\mathrm{L}_{\text {Perabot }}\right)$ dengan luas sirkulasi (LSirkulasi) dengan menggunakan persamaan berikut:

$$
\mathrm{L}_{\text {Ruang }}=\mathrm{L}_{\text {Perabot }}+\mathrm{L}_{\text {Sirkulasi }} \ldots \ldots . .
$$

Perhitungan besaran ruang yaitu mengalikan luas ruang dengan tinggi dari lantai ke langit langit (floor to ceiling) dengan menggunakan persamaan berikut:

$$
\mathrm{V}_{\text {Ruang }}=\mathrm{L}_{\text {Ruang }} \times \mathrm{H}
$$

Luas dan besaran ruang dapat dilihat pada Tabel.

Tabel 2. Luas dan Besaran Ruang Asrama Mahasiswi

\begin{tabular}{|l|r|r|}
\hline $\begin{array}{c}\text { Kelompok } \\
\text { Ruang }\end{array}$ & \multicolumn{1}{c|}{ Luas $\left(\mathbf{m}^{\mathbf{2}}\right)$} & Besaran $\left(\mathbf{m}^{\mathbf{3}}\right)$ \\
\hline Hunian & $\pm 8.328,3$ & $\pm 33.313,3$ \\
\hline Fasilitas & $\pm 3387,1$ & $\pm 15.684,1$ \\
\hline Pengelola & $\pm 322,4$ & $\pm 1.289,7$ \\
\hline Servis & $\pm 2.629,4$ & $\pm 10.517,8$ \\
\hline TOTAL & $\pm \mathbf{1 4 . 1 2 2 , 2}$ & $\mathbf{\pm 5 7 . 6 4 5 , 0}$ \\
\hline
\end{tabular}

\subsection{Tapak}

Strategi pemilihan tapak dan pengolahan tapak terhadap lingkungan fisik dicapai dengan penerapan kajian arsitektur perilaku setting perilaku untuk pemilihan tapak dan kualitas lingkungan untuk pengolahan tapak.

Pemilihan tapak didasarkan pada perilaku mahasiswi yang memiliki kecenderungan memilih hunian yang berlokasi dekat dengan universitas. Tapak terpilih yaitu berada di Jalan Lembah UGM berada sekitar $1 \mathrm{~km}$ dari UGM dan memiliki luas lahan $\pm 13.560 \mathrm{~m}^{2}$ dengan batas - batas pada sebelah utara Stadion Pancasila, timur pemukiman, selatan pemukiman, dan barat lapangan baseball.

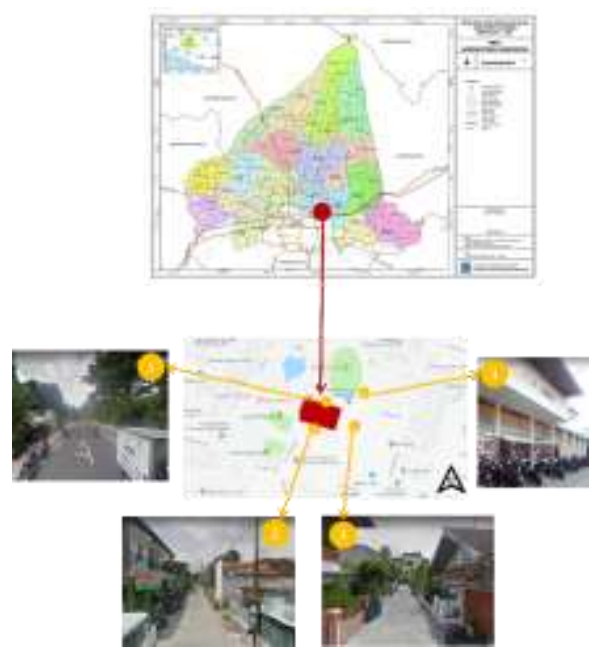

Gambar 4. Batas - batas Tapak Terpilih

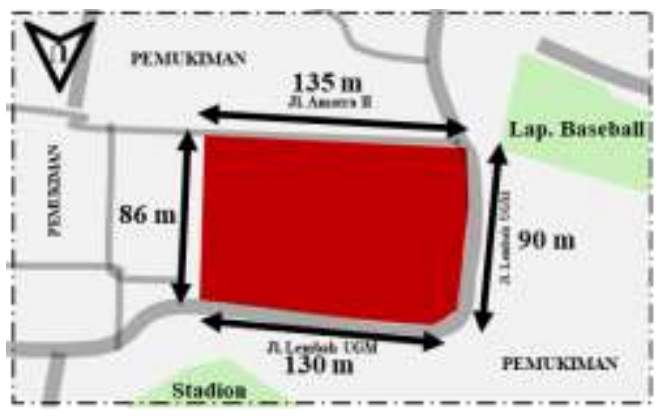

Gambar 5. Dimensi Tapak Terpilih

Pengolahan tapak terhadap pencapaian mempertimbangkan sirkulasi keluar dan masuk bangunan. Pintu masuk dan pintu keluar utama ditetapkan berada pada sebelah utara tapak yang berhubungan langsung dengan Jalan Lembah UGM yang merupakan jalan lokal sekunder karena mudah dilihar dari jalan dan mudah dijangkau dari jalan. Pintu masuk dan pintu keluar samping diletakan pada sebelah 
selatan tapak yang berhubungan langsung dengan Jalan Amarta II yang merupakan jalan kampung karena sifatnya yang tidak perlu mudah dilihat.

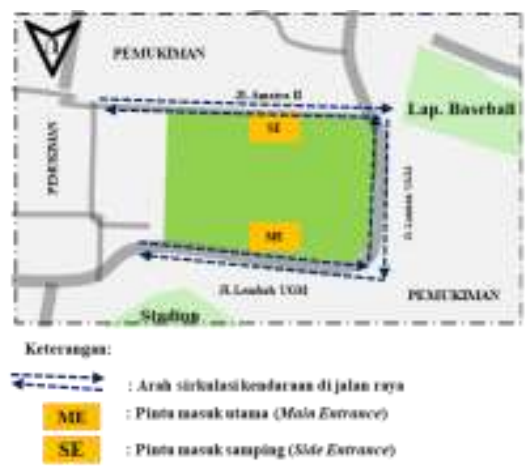

Gambar 6. Respon Pintu Masuk Utama dan Pintu Masuk Samping pada Tapak

Pengolahan tapak terhadap kebisingan mempertimbangkan sumber kebisingan, intensitas kebisingan, dan zona yang membutuhkan ketenangan. Strategi perancangannya yaitu dengan memberikan tembok pagar dan vegetasi untuk mengurangi kebisingan pada sebelah utara, barat, dan selatan tapak.

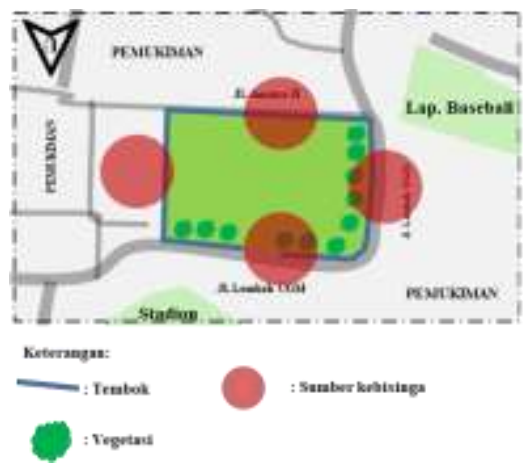

Gambar 7. Respon Tapak terhadap Kebisingan

Pengolahan tapak terhadap arah lintas matahari dan arah hembus angin mempertimbangkan sifat radiasi dan sinar matahari serta arah dan sifat hembusan angin. Strategi perancangannya yaitu tapak sebelah (1) utara dijadikan arah orientasi bangunan, (2) timur diberi vegetasi, (3) barat diberi vegetasi, dan (4) selatan diberi vegetasi.

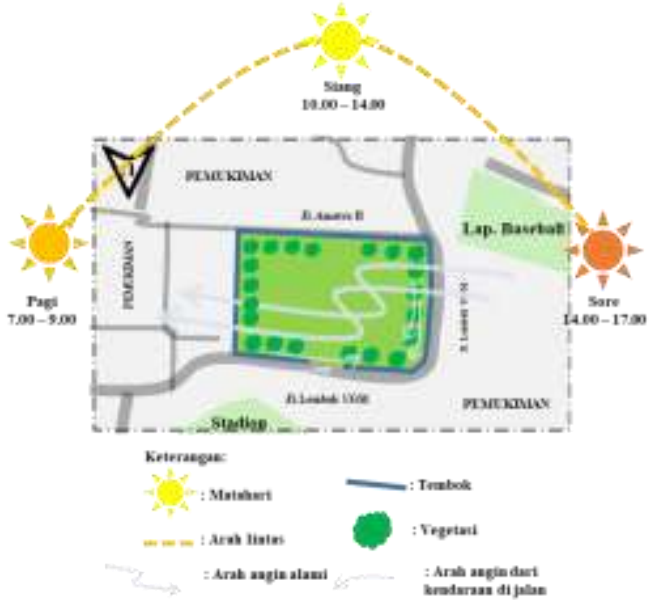

Gambar 8. Respon Tapak terhadap Arah Lintas Matahari dan Arah Hembus Angin

Pengolahan tapak terhadap sirkulasi dan zonasi mempertimbangkan (1) perilaku penghuni dan (2) kualitas lingkungan zona. Sirkulasi kendaraan mempertimbangkan pola sirkulasi kendaraan yang mungkin terjadi didalam tapak. Zonasi mempertimbangkan privasi zona hunian sehingga dilettakan pada lantai atas. Sehingga pengolahan tapak terhadap sirkulasi dapat dilihat pada Gambar 9 dan zonasi dapat dilihat Gambar 10.

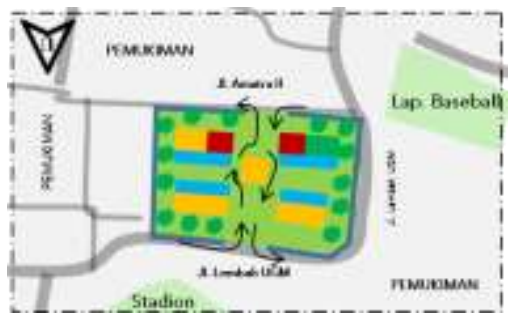

Gambar 9. Respon Pengolahan Tapak Terhadap Sirkulasi
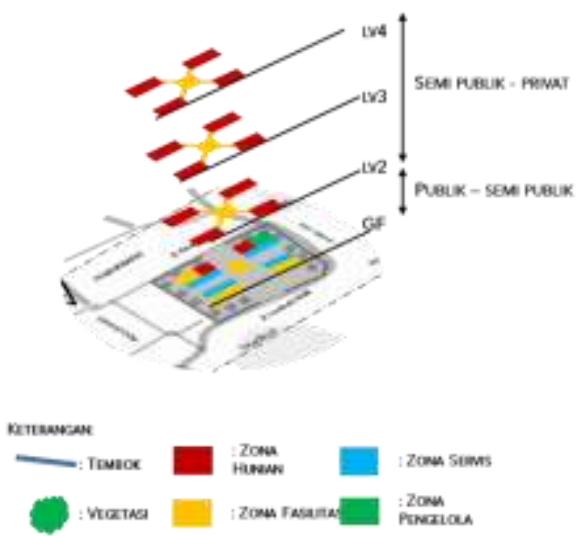

Gambar 10. Respon Sirkulasi dan Zonasi dalam Tapak 


\subsection{Tampilan Bangunan}

Strategi perancangan bentuk dasar ruang dan bentuk dasar massa bangunan menerapkan kajian arsitektur perilaku persepsi bentuk dan ruang. Bentuk dasar ruang ditetapkan bentuk segi empat dan bentuk dasar massa ditetapkan bentuk kubus atau balok karena bentuk tersebut memberikan persepsi yang mudah dipahami, memberikan efek nyaman, dan aman (Avishag Shemesh, Moshe Bar, 2015).

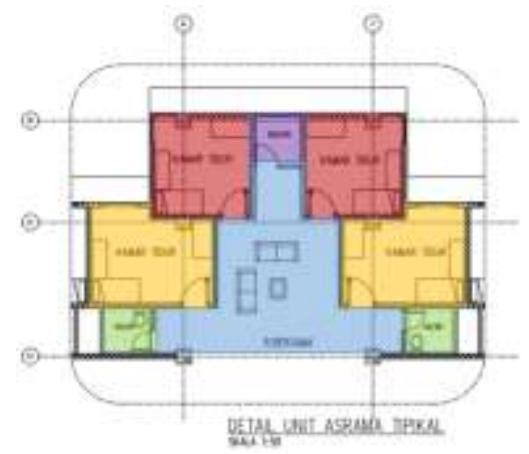

Gambar 11. Penerapan bentuk segi empat pada ruang

Strategi perancangan jenis koridor yang digunakan pada asrama mahasiswi mempertimbangkan kualitas lingkungan fisik dan kualitas lingkungan psikologis. Jenis koridor ditetapkan jenis koridor extended core plan karena (1) memungkinkan terbentuknya lingkungan yang tenang, (2) memungkinkan terjadinya ventilasi silang, (3) memungkinkan cahaya alami masuk, (4) memungkinkan terbentuknya lingkungan dengan privasi yang tinggi, (5) dan mampu melayani unit asrama dalam jumlah optimum.

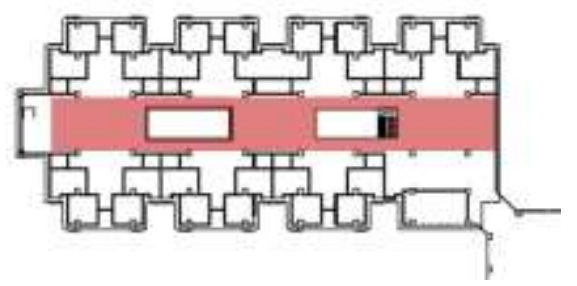

Gambar 12. Penerapan koridor jenis extended core plan

Strategi perancangan tampilan tanggap iklim menerapkan kajian arsitektur perilaku kualitas lingkungan fisik kenyamanan termal dan kenyamanan iluminasi. Tampilan bangunan yang mendukung tercapainya kenyamanan termal yaitu dengan (1) memberikan bukaan jendela dan (2) penggunaan selubung bangunan berbahan panel alumunium komposit. Tampilan bangunan yang mendukung tercapainya kenyamanan iluminasi yaitu dengan memberikan teritis pada bukaan jendela.

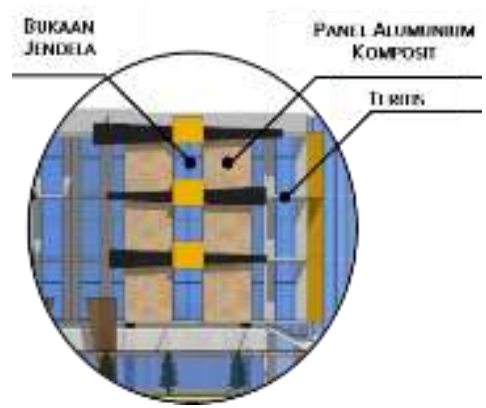

Gambar 13. Penerapan tampilan tanggap iklim

Strategi perancangan warna ruang menerapkan kajian arsitektur perilaku kualitas lingkungan psikologis dan mempertimbangkan pengaruh warna terhadap pengamat yang disesuaikan dengan karakteristik kegiatan pada ruang. Secara umum karakteristik ruang dan strategi perancangannya adalah (1) suasana netral direspon dengan warna putih, (2) suasana nyaman dengan warna coklat muda/krem, (3) suasana semangat dengan warna oren, dan (4) suasana sejuk dengan warna biru muda

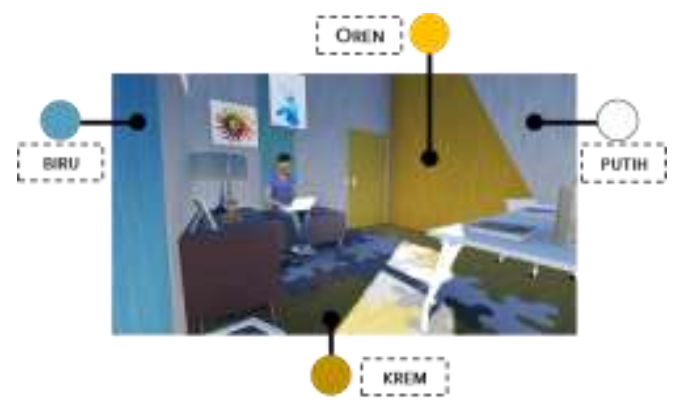

Gambar 14. Penerapan warna - warna tertentu untuk memberikan suasana tertentu

Strategi perancangan pengolahan lansekap menerapkan kajian arsitektur perilaku persepsi lingkungan. Strategi pengolahan lansekap yaitu (1) terdapat landmark, (2) terdapat jalan kendaraan dan jogging track dengan tanaman penunjuk arah cemara, (3) terdapat batas lahan berupa tembok yang mengelilingi tapak, dan (4) terdapat tempat duduk pada taman. 


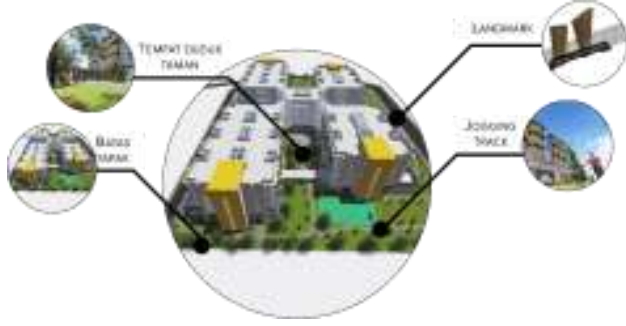

Gambar 15. Pengolahan tapak pada asrama mahasiswi

\subsection{Struktur}

Pemilihan material struktural dan sistem struktur dilakukan dengan penerapan kajian arsitektur perilaku lingkungan psikologis mengenai rasa aman. Selain itu terdapat pertimbangan - pertimbangan lain dalam pemilihannya baik material struktural maupun sistem struktur.

Material struktural pada bangunan asrama mahasiswi menggunakan material beton bertulang baja karena (1) mampu menahan beban horizontal dan vertikal serta tahan api dan karat, (2) mudah diolah dalam bentuk dan warna, dan (3) murah dalam pelaksanaan dan perawatannya.

Sedangkan sistem struktur yang digunakan mempertimbangkan (1) kekuatannya dalam menahan beban, (2) kemudahan dalam pembentukan tampilan bangunan, dan (3) pelaksanaan yang mudah serta biaya yang murah.

Sistem struktur upper struktur menggunakan atap datar beton bertulang dengan skylight rangka baja lapis galvalum. Sistem struktur supper struktur menggunakan struktur rangka. Sistem struktur sub struktur menggunakan pondasi sumuran.

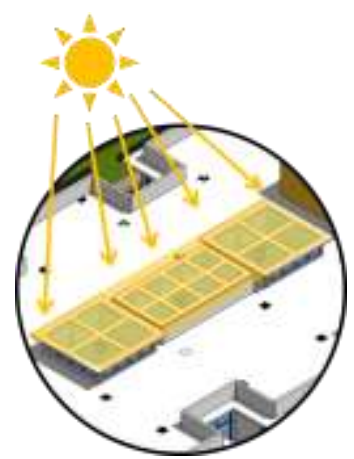

Gambar 16. Skylight sebagai jalan masuk cahaya alami dari matahari

\subsection{Utilitas}

Pemilihan sistem utilitas bangunan asrama mahasiswi secara umum menerapkan kajian arsitektur perilaku (1) setting perilaku dan (2) kualitas lingkungan fisik.

Transportasi vertikal pada bangunan asrama mahasiswi menerapkan kajian arsitektur perilaku setting perilaku berupa (1) perilaku mahasiswi dan (2) antropometri. Mahasiswi memiliki kebiasaan dan suka duduk pada tangga sehingga dirancang sebuah tangga yang nyaman untuk diduduki oleh mahasiswi dengan memperhatikan dimensi tubuh mahasiswi pada bagian komunal asrama mahasiswi.

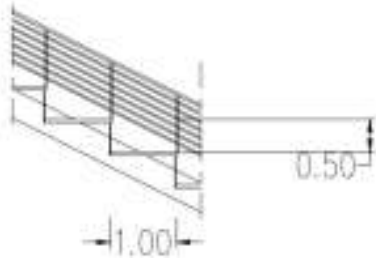

Gambar 17. Detail dimensi tangga yang dapat diduduki

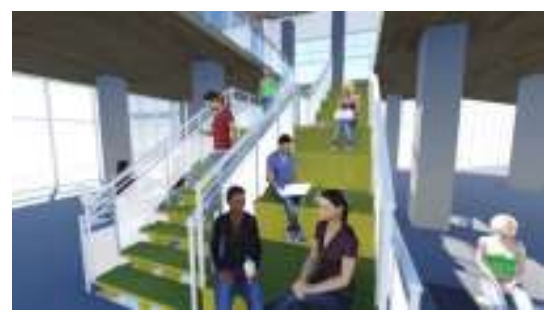

Gambar 18. Penggunaan tangga sebagai tempat duduk yang rekreatif pada komunal asrama mahasiswi

Tangga biasa dirancang dengan mempertimbangkan antropometri sehingga tercapai kenyamanan bagi penggunanya dengan lebar anak tangga $30 \mathrm{~cm}$ dan tinggi tiap anak tangga adalah $19 \mathrm{~cm}$.

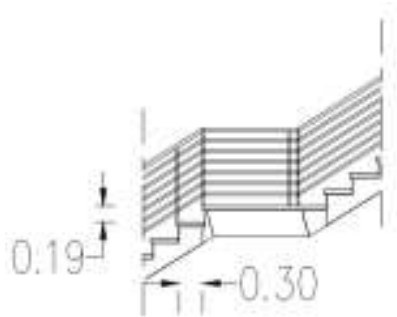

Gambar 19. Detail dimensi tangga biasa

Bangunan asrama mahasiswi dilengkapi dengan ramp yang memiliki kemiringan 1:6 sehingga memudahkan penyandang disabilitas. 
Bangunan asrama mahasiswi dilengkapi dengan pencahayaan buatan berupa lampu LED berwarna putih untuk memberikan kenyamanan bagi mahasiswi sebagai pengguna dalam melakukan berbagai macam kegiatan.

Bangunan asrama dilengkapi dengan sistem pemipaan yang akan dibedakan menjadi (1) sistem air bersih, (2) sistem pemadam sprinkler, dan (3) sistem air buangan. Sistem air buangan akan terdiri dari (1) air kotor, (2) air bekas, (3) air hujan (Gambar 20).

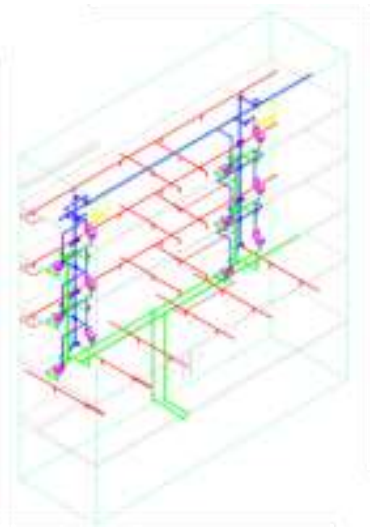

Gambar 20. Detail aksonometri pemipaan

\subsection{Hasil Akhir}

Metode perencanaan dan perancangan arsitektur perilaku menghasilkan rancangan asrama mahasiswi sebagai berikut.

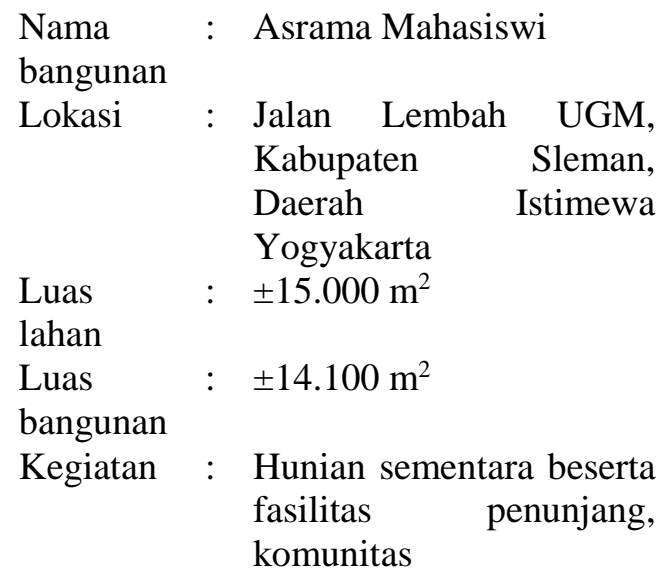

\section{KESIMPULAN}

Asrama mahasiswi yang dirancang untuk mengakomodasi kebutuhan hunian sementara bagi mahasiswi khusunya mahasiswi baru yang membutuhkan kenyamanan dan ketenangan untuk menunjang dalam aktivitas hunian dan pengembangan diri.
Kajian - kajian arsitektur perilaku dalam perancangan bangunan asrama mahasiswi di Sleman diterapkan secara menyeluruh pada persoalan - persoalan sehingga tercapai rancangan yang memperhatikan aspek fungsional dan aspek pengguna.

Pendekatan arsitektur perilaku merupakan sebuah metode perencanaan dan perancangan yang tepat diterapkan pada perancangan asrama mahasiswi karena sesuai dengan kriteria bangunan hunian yang memperhatikan aspek fungsional dan aspek pengguna.

\section{DAFTAR PUSTAKA}

Avishag Shemesh, Moshe Bar, Y. J. G. (2015). Space and Human Perception - Exploring Our Reaction to Different Geometries of Spaces. Computer-Aided Architectural Design Research in Asia CAADRIA 2015, 20(Computer-Aided Architectural Design), 10.

Halim, D. (2005). Psikologi Arsitektur: Pengantar Kajian Lintas Disiplin. Jakarta: PT Grasindo.

Harris, C. M. (2006). Dictionary of Architecture \& Construction. New York: McGraw-Hill.

Haryadi, \& Setiawan, B. (2014). Arsitektur Lingkungan dan Perilaku: Suatu Pengantar ke Teori, Metodologi, dan Aplikasi (2nd ed.). Yogyakarta: Gadjah Mada University Press.

Krissanti, K., Singgih, E. P., \& Nugroho, R. (2014). Hunian dan Pelayanan Lanjut Usia Dini di Kabupaten Bogor dengan Penekanan Perilaku dalam Arsitektur. Arsitektura, 12(Arsitektur dan Lingkungan Binaan), 9.

Noguchi, H. (1978). Educational Building Digest: Design Guide for Student Housing. Bangkok: Unesco Regional Office for Educational in Asia and Oceania.

Suminar, E. Y., Marsudi, \& Handayani, K. N. (2016). Kalianyar Vertikal Kampong with Behavior Architecture in Jakarta. Arsitektura, 14(Arsitektur dan Lingkungan Binaan), 10. 